\author{
Bayan Arqawi \\ Affiliation: Bond University \\ Address: School of Business \\ Bond University \\ Gold Coast, Queensland, 4229 \\ Australia \\ Email: barqawi@bond.edu.au
}

William J. Bertin*

Affiliation: Bond University

Address: School of Business

Bond University

Gold Coast, Queensland, 4229

Australia

Phone: +617 55952210

Email: wbertin@bond.edu.au

Laurie Prather

Affiliation: Bond University

Address: School of Business

Bond University

Gold Coast, Queensland, 4229

Australia

Phone: +617 55952073

Email: lprather@bond.edu.au

* Corresponding author 


\title{
The Impact of Product Warranties on the Capital Structure of Australian Firms
}

\begin{abstract}
This paper examines the impact of Australian firms' warranty policies on their capital structures. The sample consists of 261 firms and 937 firm-years for Australian public firms for the period 2007-2010. The results suggest that warranty policies impact on Australian firms' capital structures. Consistent with earlier Australian studies, size and asset tangibility are positively related to leverage; growth and profitability are negatively related to leverage; and earnings volatility and industry concentration are unrelated to leverage. In addition to these previously identified relationships, the firms' warranty policies have a negative impact on leverage.
\end{abstract}




\section{Introduction}

Jensen and Meckling (1976) define the firm as a nexus for contracting relationships between individuals. This study considers one of the firm's contracts, namely product warranties. Generally, a product warranty is a contract between the firm and its customers which guarantees that the product is reliable and free from known defects and that the firm, under certain specified conditions, will repair or replace defective parts that may arise within a prescribed period of time. Australian companies have been required to disclose warranty claims and warranty provisions in their annual reports since 2001 pursuant to AASB 137 'Provisions, Contingent Liabilities and Contingent Assets’ and its predecessor AASB $1044 .^{1}$

Kale, Meneghetti, and Shahrur (2010) consider the impact of product warranties on US firms' capital structures and find a negative association between leverage and product warranties. This paper extends Kale, et al.’s (2010) study to the Australian market by examining whether product warranties influence Australian firms’ capital structures. A number of other factors, however, may distinguish the capital structure choice for Australian firms when compared to US firms. For one, the Australian corporate bond market is smaller, less liquid, and more concentrated than the US bond market, which naturally leads to lower Australian debt levels. Secondly, as documented in Battellino and Chambers (2006), Australian businesses tend to rely heavily on bank loans and the equity market as their main source of long term external funds. Finally, in contrast to the traditional or classical tax system found in the US, in 1987 Australia adopted a dividend imputation tax system. Under dividend imputation equity is a lower cost source of financing, and employing this system has caused a significant reduction of debt levels among Australian firms (Twite, 2001). Given the differences in the Australian and US regulatory frameworks and in the structure of their respective capital markets, we

\footnotetext{
${ }^{1}$ AASB 1044 'Provisions, Contingent Liabilities and Contingent Assets' was issued in 2001 as part of the AASB's effort to narrow the gap between Australian Accounting Standards and International Accounting Standards. AASB 137 replaced AASB 1044 and is applicable from the first reporting period beginning on or after 1 January 2005.
} 
investigate whether the negative relationship between leverage and the level of product warranties established for US firms also exists for Australian firms. The study conducts both univariate and multivariate analyses using a sample of 261 firms (937 firm-years) listed on the Australian Securities Exchange (ASX) for the period 2007-2010.

The findings suggest that warranty policies affect the capital structure of Australian firms. In particular, the results indicate a negative relationship between warranty provisions and leverage. The findings are also consistent with earlier Australian studies in that size and asset tangibility are positively related to leverage; growth and profitability are negatively related to leverage; and earnings volatility and industry concentration are unrelated to leverage.

The paper is organised as follows; section 2 presents the literature on capital structure theories and the empirical evidence concerning capital structure in Australia; section 3 develops the hypothesis; section 4 describes the data and the methodology; section 5 explains the construction of variables; section 6 provides descriptive statistics of the data; section 7 reports the findings; and section 8 concludes.

\section{Literature Review}

In the seminal research on capital structure, Modigliani and Miller (M\&M) (1958) provide the theoretical basis for discussions on the topic. In support of irrelevance, M\&M Proposition I states that the value of the firm is constant regardless of the capital structure; M\&M Proposition II states that the cost of equity capital is a linear function of the debt-equity ratio. In perfect capital markets $M \& M$ argue that capital structure is irrelevant, however, the relaxation of the strict assumptions alters the predictions of the classic theory. The following literature considers various market imperfections including taxes, bankruptcy costs, and agency costs, however, retains the assumptions of market efficiency. 
Modigliani and Miller (1963) and Miller and Modigliani (1966) add corporate taxes to their previous model. With interest payments being tax deductible, they argue that the value of the firm increases by using debt and hence the levered firm's value equals that of the unlevered firm plus the debt tax shield's value. Miller (1977) relaxes model assumptions further by introducing personal taxes in addition to the corporate taxes. Results suggest that "under certain conditions, the tax advantage of debt financing at the firm level is exactly offset by the tax disadvantage of debt at the personal level” (Bradley, Jarrell, and Kim, 1984, p. 857). DeAngelo and Masulis (1980) extend Miller's model by analysing the effect of tax shields other than interest payments. They argue that non-debt corporate tax shields (i.e. depreciation, investment tax credits, etc.) may negate the leverage irrelevancy theorem. Their model predicts that there is a unique optimal debt level for each firm, which is negatively related to the level of non-debt tax shields.

Kraus and Litzenberger (1973) incorporate bankruptcy costs in the trade-off theory of capital structure where firms choose the level of debt and equity financing by balancing the direct bankruptcy costs and the debt tax saving benefits. Several others including Warner (1977), Altman (1984), and Opler and Titman (1994) provide further evidence on the cost of bankruptcy with the general conclusion that the indirect costs are significant and may excede the direct bankruptcy costs. Leland (1994) proposes a model to value the firm where the optimal capital structure is a trade-off between the value created by the present value of the interest tax shield and the value lost from the present value of bankruptcy costs.

Agency cost is another element of market imperfections in the capital structure debate. Proponents of agency theory argue that firms in the US used debt even before income taxes existed, hence factors other than debt tax shields and bankruptcy costs explain optimal leverage usage (Copeland, et al., 2005). Jensen and Meckling (1976) introduce the agency costs (of debt and equity) and argue that increasing debt levels cause risk-shifting, which 
increases the agency costs of debt while the agency costs of equity decrease. Thus the optimal capital structure minimises total agency costs. Jensen (1986) argues that high equity levels may cause free cash flow problems and conflicts of interest between shareholders and managers. To overcome this problem, he proposes using debt to restrict managerial discretion and thus reduce the agency cost of equity.

Ross (1977) considers capital structure variations through signalling theory. In the presence of asymmetric information, Ross argues that managers will use the financial structure of the firm to send unambiguous signals to the public about the firm's future performance. For example, a new equity offering signals an overvalued stock, while new debt financing signals undervalued shares and positive future performance. Myers and Majluf (1984) and Myers (1984) consider the capital structure decision differently in developing the pecking order theory that supports a financing hierarchy among firms. Their model analyses an operating firm with a growth potential that needs financing. A new equity offering is perceived as good news if it represents a growth opportunity or alternatively bad news if managers believe that the share price is overvalued. In specifying no target debt level, pecking order merely aims to explain the corporate financing behaviour where high growth firms with lower operating cash flows and high financing needs use high debt levels while more profitable firms with high internal cash flows use less debt.

A number of empirical studies investigate capital structure determinants in various countries. Frank and Goyal (2009) investigate determinants for publicly traded US firms from 1950 to 2003. They find that median industry leverage, log of assets, tangibility, and expected inflation have a positive impact on leverage, while market-to-book assets ratio and profits have a negative impact. In a prior study, Rajan and Zingales (1995) find similar results for the major industrialised countries (G-7). In particular, they find that capital structure determinants in the G-7 countries have similar correlation relationships as those of US firms, 
and the aggregate debt ratio is similar across the G-7 countries, although such results are difficult to explain theoretically.

Capital structure determinants of Australian firms may be different than US firms due to structural and regulatory differences. While empirical studies widely support the tax advantage of debt financing in the US, it may not be as applicable in Australia. Prior to 1987, both Australia and the US operated under a double taxation system with dividends taxed at both the corporate and personal levels. In 1987 Australia implemented a tax imputation system effectively taxing dividends only once at the Australian investor's marginal tax level. This imputation system creates a tax induced preference for equity and thus lowers the tax advantage of debt, which ultimately influences investors’ debt/equity preferences.

Several studies examine Australian firm characteristics and capital structure; however, as Qiu and La (2009) note, they provide inconclusive results. During the pre-1987 double taxation period, Allen (1991) provides evidence that Australian firms follow a pecking order and maintain spare debt capacity with firms mostly concerned about their financial flexibility and tax, and that less debt is associated with more profitable firms. After the adoption of the dividend imputation tax system, however, Twite (2001) reports a large reduction in Australian firms' debt ratios and an increase in the proportion of capital raised by equity. Cassar and Holmes (2003) find that the capital structure of Australian firms support both static trade-off and pecking order theory, but contradicts the bankruptcy costs theory. They also report that growth firms have higher debt ratios, more profitable firms with fewer tangible assets have lower ratios, and risk (measured by variation of profitability) is not a significant factor in debt decisions. Deesomsak, Paudyal, and Pescetto (2004) investigate capital structure determinants in four Asia Pacific countries (Thailand, Malaysia, Singapore, and Australia). They report that asset tangibility and size have a positive effect on Australian firms’ leverage; non-debt tax shields, share price performance, and liquidity have a negative 
effect on leverage; and profitability, growth, and risk have no effect on leverage. The authors note, however, that country-specific legal and institutional environments may impact capital structure.

Qiu and La (2009) compare capital structures across Australian firms by examining firmspecific characteristics for 367 firms over the period 1992-2006. Australian firms carrying no debt tend to have lower proportions of tangible assets, higher growth potential, a relatively smaller size, less profit, and more risk than levered firms. For levered firms, the debt ratio is positively associated with asset tangibility, but negatively associated with growth and business risk. The authors suggest that the main determinants of Australian firms' capital structure are bankruptcy costs, agency costs, security issuance costs, and associated signalling effects, thus supporting both the pecking order and the agency cost theories, while contradicting the trade-off theory.

Hamson (1993) examines the cross-sectional variation in debt maturity for 475 US firms and 292 Australian firms by using both the total level of debt (interest and non-interest bearing) and the maturity of debt. Although not a comparative study, he notes that Australian firms tend to have lower debt levels but larger amounts of short term debt than US firms. The study reports a positive relationship between firm size and debt maturity, maturity and debt levels, debt maturity and the maturity of assets in place (supporting the matching principle), and assets in place and leverage (supporting the static trade-off theory). The results provide mixed support for the pecking order theory (strong in the total and US samples but much weaker in the Australian sample) and limited support for the tax based theory of capital structure.

More recently, Alcock, Finn, and Tan (2011) investigate the determinants of debt maturity choices for the top 147 Australian firms over the period 1989-2006. The study finds a positive relationship between leverage and maturity and supports the signalling hypothesis 
where Australian companies signal their high quality by using short term debt, but the findings do not support traditional debt maturity theories. The authors attribute the results to the structural and regulatory differences between Australia and the US; specifically the Australian dividend imputation tax system, the heavy reliance of Australian firms on bank loans, and the relatively small and illiquid Australian corporate bond market.

\section{Hypothesis Development}

Titman (1984) states that the agency relationship between the firm and its non-financial stakeholders exists because the liquidation decision (controlled by the firm) imposes costs on the non-financial stakeholders (customers, employees, and suppliers). He illustrates the relationship between the firm and its customers; if the firm produces durable goods that require future specialised servicing, customers are not only paying for the product but also for the availability of expected future services. If the firm goes bankrupt, its customers lose their anticipated services. Consequently, before doing business with the firm, customers assess the probability of bankruptcy, thus creating high indirect bankruptcy costs for the firm. As a result, firms reduce the probability of bankruptcy by lowering debt levels (Copeland, et al., 2005, p. 595). Maksimovic and Titman (1991) link the financing policy of the firm with its reputation for product quality. They argue that, even if customers do not bear costs from the firm going bankrupt, customers will be unwilling to trade with highly levered firms because high levels of debt can influence the firm's incentive to honour its implicit contracts, and this negatively affects the perceived quality of its products.

Telser (1980) proposes a theory of self-enforcing agreements. He argues that the firm with a self-enforcing agreement will always choose to honour the claims because the potential losses (future sales and reputation) arising from violation of the agreement are higher than the potential gains arising from dishonouring the agreement. In other words, the terms of the self 
enforcing agreement are such that adherence is more advantageous than violation. Telser also argues that customers assess the reliability of the seller and avoid making transactions with unreliable sellers. Appelbaum (1992) addresses the impact of product warranty contracts on capital structure and argues as follows: bondholders have a higher priority in bankruptcy than consumers, which increases the risk facing consumers, and given risk-averse consumers and risk neutral financial claimants, then debt usage requires a higher risk premium in the consumers' contract making debt too costly. Thus, the firm has an incentive to lower its debt level and customers' risk. In other words, the firm uses the capital structure as a risk shifting tool to allocate risk optimally between the firm's contractual parties. The optimal allocation shifts risk away from risk-averse consumers by using full equity financing.

In summary, the literature provides that product warranties are important tools for risk shifting. Since the capital structure of the firm influences its ability to honour future obligations, the existence of product warranty contracts is expected to affect the firm's debt level. This study tests the hypothesis that there is negative relationship between leverage and product warranties for Australian firms.

\section{Data}

Data on product warranty provisions are collected from company annual reports. AspectHuntley FinAnalysis database provides the firm characteristic data for the fiscal years 2007 - 2010. Consistent with Kale, et al. (2010), the sample excludes financial firms (GICS codes between 4010-4040) and utilities (GICS code 5510). The final sample consists of 261 Australian listed firms (equivalent to 937 firm-years) with complete characteristic data for variable construction.

According to the AASB 137 'Provisions, Contingent Liabilities and Contingent Assets', the firm should recognise a provision in the financial statements when the firm has a present 
obligation (legal or constructive) as a result of a past event; it is probable that an outflow of resources will be required to settle the obligation, and a reliable estimate can be made of the amount of the obligation. ${ }^{2}$ Firms offering product warranties and meeting the recognition criteria will report product warranty provisions in their financial statements. However, other firms which offer product warranties but do not meet any of the recognition criteria, will not report product warranty provisions. Hence the presence of product warranty provisions means that a firm offers an explicit product warranty, but the absence of this provision does not necessarily mean that the firm is not offering product warranties; it may either be implicitly offering product warranties or alternatively, offering no warranties.

Following Kale, et al. (2010), the sample of firms is divided into three mutually exclusive groups; 1) firms that report product warranty provisions in their financial statements are classified as explicit warranty firms (EWF); 2) firms which do not report product warranty provisions but operate in an industry where at least one firm offers explicit product warranties are classified as implicit warranty firms (IWF); and finally, 3) firms which do not report product warranty provisions and operate in an industry where none of the firms offer explicit product warranties are classified as non-warranty firms (NWF). The classification of firms into EWF, IWF or NWF groups is based on a firm-year perspective. For example, if a firm in a warranty industry does not offer explicit product warranties in a given year but does in other years, it is classified as IWF in the former case and EWF in the latter.

The industries are sorted into two groups; if at least one firm in the industry offers explicit product warranties, then the industry is classified as a warranty offering industry (WI), and if none of the firms within the industry offer product warranties, then the industry is classified as a non-warranty offering industry (NWI).

\footnotetext{
${ }^{2}$ Australian Accounting Standards Board, 2010
} 


\section{Measurement of Variables}

To measure the relationship between product warranties and capital structure for Australian firms, this study specifies Leverage, a proxy for capital structure, as the dependent variable. The independent variable used to measure the firm's level of warranty is Warranty Provisions (WP). Firms that do not offer explicit product warranties are assigned a value of zero for this variable. As in Kale, et al. (2010), this study includes the lagged values for all firm-specific control variables: Size, ROA, ROA Volatility, Asset Collateral Value, Tobin's Q, Herfindahl Index, Total Accruals, Non-Debt Tax Shields, and R\&D Intensity. Two variables, Dividend Yield and Franked Dividend are also included in the analyses to model the Australian imputation tax system. The definitions of variables are presented in Table 1. Wherever appropriate, regressions include 4-digit GICS industry code and year dummies. All continuous variables are winsorised at the $1^{\text {st }}$ and $99^{\text {th }}$ percentiles.

[Insert Table 1 about here]

\section{Descriptive Statistics}

Table 2 presents the descriptive statistics of WP. The sample consists of 261 firms spread across 17 different industry groups (according to the GICS 4 digit codes). Nine of the industries are categorised as warranty industries (WI) where at least one firm has a positive provision for product warranties.

\section{[Insert Table 2 about here]}

There are 937 firm-year observations; 16\% of the observations (with positive warranty provisions) are classified as EWFs, 37\% of the observations (with zero warranty provisions operating in WI) are classified as IWFs; and 47\% of the observations (with zero warranty provisions and operating in NWI) are classified as NWFs. The mean (median) values of WP 
are $0.115 \%(0.000 \%)$ for the whole sample and $0.713 \%(0.513 \%)$ for the sub-sample of firms with positive warranty provisions.

Non-zero warranty provisions are dominant in industries that sell durable goods. The industries ranked according to their respective WP means are; Technology Hardware and Equipment (1.226\%), Consumer Durables and Apparel (1.021\%), Software and Services (0.816\%), Health Care Equipment and Services (0.808\%), Capital Goods (0.714\%), Automobile and Components (0.644\%), Commercial and Professional Services (0.500\%), Consumer Services (0.309\%), and Food, Beverage and Tobacco (0.176\%).

Table 3 presents the descriptive statistics of the firms' characteristic variables and Pearson correlation coefficients. The average value of Leverage is $20.30 \%$ and the median value is 16.33\%. There are 133 observations (14.19\% of the sample) with zero leverage (all equity financed); nine are classified as EWF, 32 are IWF, and 92 are NWF. Similar to Kale, et al. (2010) Table (3) shows that the correlation for WP with Leverage is negative, however for Australian firms it is not statistically significant. Also consistent with the findings of Kale, et al. (2010), Size, Asset Collateral Value, and ROA are positive and significantly correlated with Leverage, while ROA Volatility and Tobin's $Q$ are negatively correlated with Leverage. Dividend Yield is positive and significantly related to Leverage as well as firm size and profitability as measured by $R O A$. WP is negatively correlated with the Asset Collateral Value and positively correlated with $R \& D$ Intensity.

[Insert Table 3 about here] 


\section{Findings: Univariate and Multivariate Analyses}

Table 4 presents the t-test (Kruskal-Wallis test) results from the univariate analysis to determine whether the mean (median) characteristics of firms across different sub-samples based on warranty policy are statistically different.

\section{[Insert Table 4 about here]}

Panel A of Table 4 reports results comparing firms that have positive warranty provisions to those that do not [EWF vs. (NWF and IWF)]. There is no statistical difference in the mean Leverage of warranty firms and non-warranty firms. However, the median Leverage for firms offering warranties (0.2030) is significantly higher than the median Leverage for firms without warranty provisions $(0.1548)$. This finding is inconsistent with the hypothesis that firms that offer product warranties choose lower debt levels. Further, firms with warranty provisions have on average lower asset collateral values and belong to less concentrated industries. These results are inconsistent with Kale, et al. (2010, p. 14); they find that the mean (median) leverage for firms offering warranties is significantly lower than firms without warranty provisions and firms with warranty provisions belong to more concentrated industries. The mean (median) values of ROA and ROA Volatility show that firms with warranty provisions are more profitable and have less variability in their operating income than firms without warranty provisions.

Panel B of Table 4 compares the characteristics of firms in WI, including both EWF and IWF, with those in NWI [WI vs. NWI]. The mean (median) Leverage of firms in WI of 0.2235 (0.1919) is significantly higher than the mean (median) Leverage of firms in NWI of 0.1794 (0.1261). Firms in WIs are more profitable, have a higher dividend yield, lower asset tangibility, and operate in less concentrated industries than firms in NWI. 
Panel C of Table 4 compares the sub-samples of firms that do not offer product warranties but operate in warranty industries with those that do not offer product warranties and operate in NWIs [IWF/WI vs. NWI]. The mean (median) Leverage of IWFs is statistically higher than the mean (median) Leverage of firms in NWIs. Finally, Panel D of Table 4 compares firms in warranty industries with positive warranty provisions with firms in warranty industries but with zero warranty provisions (EWF vs. IWF). The results show that the mean (median) Leverage is not statistically different for the two sub-samples.

The results of the univariate analysis show that firms in WI have higher Leverage than firms in NWI. Similarly, IWFs have higher leverage than NWFs, however, there is no statistical difference between the Leverage of EWFs and IWFs. These initial findings do not support the hypothesis that firms offering product warranties have lower debt levels.

To further refine the analysis, Tables 5, 6 present the results of multivariate OLS regressions. To analyse the relationship between corporate leverage and warranty policies, the variable Leverage is the dependent variable while WP serves as the independent variable in addition to several control variables for other identified determinants of debt. Table 5 presents the OLS regression coefficients of Leverage on WP for the whole sample of 937 firm-years.

The first column in Table 5 presents a model comparable to Kale, et al.'s (2010). The coefficient on WP is negative but statistically insignificant from zero. However when Franked Dividends and Dividend Yield, which model the Australian imputation tax system, are included in the regressions (second column), the coefficients on WP are negative (-2.801) and significant. This finding shows that warranty contracts do impact on leverage for Australian firms; firms with warranty provisions tend to have lower debt levels. Based on the estimated regression coefficients, the leverage of a firm with average Warranty Provisions increases by two percent if that firm reduces its Warranty Provisions to zero. 
[Insert Table 5 about here]

The coefficients on the control variables are consistent with the existing literature. Size and Asset Collateral Value (a measure of asset tangibility) are significant and positively related to leverage. These results are similar to those found in other international and Australian studies [(Harris and Raviv, 1991), (Rajan and Zingales, 1995), (Frank and Goyal, 2009) (Deesomsak, et al., 2004), and (Cassar and Holmes, 2003)].

The coefficients on ROA (a profitability variable) are significant and negative, which suggests that more profitable firms use less leverage. This result supports the pecking order theory and is consistent with the international evidence [(Titman and Wessels, 1988), (Rajan and Zingales, 1995), (Fama and French, 2002), and (Frank and Goyal, 2009)]. Relative to the Australian capital structure literature, these results are counter to Deesomsak, et al. (2004) who find that profitability does not relate to leverage in Australian firms. However, the negative relationship between debt level and profitability is consistent with both Qiu and La (2009) and Cassar and Holmes (2003).

The coefficients on Tobin's Q (a measure of growth potential) are significant and negative. This is consistent with the findings of international studies [(Long and Malitz, 1985; Smith and Watts, 1992; Barclay, Smith and Watts, 1995; Barclay and Smith, 1999) cited in Myers (2001, p. 83)]. The Australian literature again provides inconclusive results; Qiu and La (2009) find that firms with valuable growth opportunities tend to have low debt ratios, Cassar and Holmes (2003) find that debt ratio is positively related to growth, and Deesomsak, et al. (2004) find that growth does not relate to leverage in Australian firms.

The coefficients on ROA Volatility (measure of risk) are not statistically significant. This result is consistent with Deesomsak, et al. (2004), but inconsistent with Qiu and La (2009) and Bradley, et al. (1984) who report that risk (measured as the unlevered beta of equity in 
Qiu and La (2009) and measured as volatility of earnings in Bradley, et al., (1984)) is negatively related to debt ratio.

While Dividend Yield is positively related to Leverage, the coefficient on Franked Dividend is negative and significant. This finding suggests that firms which pay franked dividends tend to have lower debt levels; this is consistent with Twite (2001) who reports that the adoption of dividend imputation causes a significant reduction of debt levels among Australian firms.

Table 6 reports the regression coefficients for the sub-sample of firms operating in WIs; the first, second, and third columns report the regression coefficients for all firms operating in WIs, firms in WIs that manufacture durable goods, and firms in WIs that manufacture nondurable goods, respectively.

The coefficient on WP is negative and not significantly different from zero for the sub-sample of firms in WI (column 1). Titman and Wessels (1988) suggests that firms manufacturing durable goods will find liquidation costly and hence are financed with less debt. To test the relationship between product warranties and leverage based on industry type, columns 2 and 3 of Table 6 present the regression coefficients for firms selling durable goods and nondurable goods, respectively. The WP coefficient for firms in WIs that sell durable goods is negative but not significant (column 2). However, the coefficient on WP for firms selling non-durable goods (column 3) is negative and statistically significant. Although this finding differs from Kale, et al. (2010), it supports the notion that the leverage decision for producers of non-durable (durable) goods is more closely aligned with creditors concern regarding product value in the event of bankruptcy as opposed to consumers concern regarding the product servicing. Given that non-durable goods are typically short term and considered as consumables, their liquidation values would be lower than those of durables goods. The 
lower value of the non-durable products outweighs the lower cost of liquidation (product servicing), suggesting that non-durable goods manufacturers hold less debt. ${ }^{3}$

\section{Conclusions}

This paper extends Kale, et al.’s (2010) study by considering Australian firms and examines the impact of firms' warranty policies on capital structure. The dataset consists of 937 firmyears for Australian public firms for the period 2007-2010. The variables used are similar to Kale, et al.’s (2010), however, two variables, Dividend Yield and Franked Dividend are also included to model the Australian imputation tax system.

Results indicate that warranty policies impact Australian firms' capital structure decisions. In particular, after adjusting for the advantage of equity via dividend imputation, firms offering product warranties have lower leverage. Size and asset tangibility are positively related to leverage; while growth and profitability are negatively related to leverage. Earnings volatility and industry concentration are unrelated to leverage. These findings are consistent with earlier Australian studies such as Deesomsak, et al. (2004), Qiu and La (2009) and Cassar and Holmes (2003).

Although some of our results are similar to Kale, et al. (2010), the findings imply potential differences in capital structure determinants between the US and Australian firms. Alcock, et al. (2011) highlight the Australian structural and regulatory differences that cause capital structure determinants to differ from those in the US. Firstly, Australia follows the dividend imputation tax system which has resulted in Australian firms reducing their debt borrowing significantly. Secondly, Australia has a relatively small, concentrated, and less liquid bond market compared to the US. Finally, Australian firms depend heavily on bank financing.

\footnotetext{
${ }^{3}$ Another explanation for this divergence in findings can be attributed to the industry classification systems; Kale, et al. (2010, p. 14) use SIC code while this study uses GICS code. The SIC and GICS schemes sometimes disagree about a company's industry assignment (Chan, Lakonishok, and Swaminathan, 2007). A relatively small sample of non-durable firms may also be a factor.
} 


\section{References}

Alcock, J., Finn, F., and Tan, K. J. K. (2011). The determinants of debt maturity in Australian firms. Accounting \& Finance.

Allen, D. E. (1991). The Determinants of the Capital Structure of Listed Australian Companies: The Financial Manager's Perspective. Australian Journal of Management, 16(2), 103-128.

Altman, E. I. (1984). A Further Empirical Investigation of the Bankruptcy Cost Question. The Journal of Finance, 39(4), 1067-1089.

Appelbaum, E. (1992). Bankruptcy, Warranties and the Firm's Capital Structure. International Economic Review, 33(2), 399-412.

AASB 137: provisions, contingent liabilities and contingent assets (2010).

Battellino, R., and Chambers, M. (2006). An overview of the Australian corporate bond market: Bank for International Settlements.Bradley, M., Jarrell, G. A., \& Kim, E. H. (1984). On the existence of an optimal capital structure: theory and evidence. The Journal of Finance, 39(3), 857-878.

Cassar, G., and Holmes, S. (2003). Capital structure and financing of SMEs: Australian evidence. Accounting \& Finance, 43(2), 123-147.

Chan, L.K., Lakonishok, J., and Swaminathan, B. (2007). Industry classifications and return comovement. Financial Analysts Journal, 63(6), 56-70.

Copeland, T. E., Weston, J. F., and Shastri, K. (2005). Capital structure and the cost of capital: theory and evidence. In t. ed (Ed.), Financial Theory and Corproate Policy (pp. 557-643). USA: Pearson.

DeAngelo, H., and Masulis, R. W. (1980). Optimal capital structure under corporate and personal taxation. [doi: DOI: 10.1016/0304-405X(80)90019-7]. Journal of Financial Economics, 8(1), 3-29.

Deesomsak, R., Paudyal, K., and Pescetto, G. (2004). The determinants of capital structure : evidence from the Asia Pacific region. Journal of Multinational Financial Management, 14, 387-405.

Durand, D. (1952). Cost of Debt and Equity Funds for the Business: Trends and Problems of Measurement. Paper presented at the Research in Business Finance National Bureau of Economic Research.

Fama, E. F., and French, K. R. (2002). Testing trade-off and pecking order predictions about dividends and debt. Review of Financial Studies, 15(1), 1-33.

Frank, M. Z., and Goyal, V. K. (2009). Capital Structure Decisions: Which Factors Are Reliably Important? Financial Management, 38(1), 1-37.

Hamson, D. F. (1993). An Empirical examination of corporate capital structure in Australia and the USA Unpublished PhD Thesis, The University of Queensland Brisbane.

Harris, M., and Raviv, A. (1991). The Theory of Capital Structure. The Journal of Finance, 46(1), 297-355.

Jensen, M. C., and Meckling, W. H. (1976). Theory of the firm: Managerial behavior, agency costs and ownership structure. [doi: DOI: 10.1016/0304-405X(76)90026-X]. Journal of Financial Economics, 3(4), 305-360.

Kale, J. R., Meneghetti, C., and Shahrur, H. K. (2010). Explicit and Implicit Contracts with NonFinancial Stakeholders and Corporate Capital Structure: The Case of Product Warranties. SSRN eLibrary.

Kraus, A., and Litzenberger, R. H. (1973). A State-Preference Model of Optimal Financial Leverage. The Journal of Finance, 28(4), 911-922.

Leland, H. E. (1994). Corporate Debt Value, Bond Covenants, and Optimal Capital Structure. The Journal of Finance, 49(4), 1213-1252. 
Maksimovic, V., and Titman, S. (1991). Financial policy and reputation for product quality. Review of Financial Studies, 4(1), 175-200.

Miller, M. H. (1977). Debt and Taxes. The Journal of Finance, 32(2), 261-275.

Miller, M. H., and Modigliani, F. (1966). Some Estimates of the Cost of Capital to the Electric Utility Industry, 1954-57. The American Economic Review, 56(3), 333-391.

Modigliani, F., and Miller, M. H. (1958). The cost of capital, corporation finance and the theory of investment. The American Economic Review, 48(3), 261-297.

Modigliani, F., and Miller, M. H. (1963). Corporate Income Taxes and the Cost of Capital: A Correction. The American Economic Review, 53(3), 433-443.

Myers, S. C. (1984). The Capital Structure Puzzle. The Journal of Finance, 39(3), 575-592.

Myers, S. C. (2001). Capital structure. The Journal of Economic Perspectives, 15(2), 81-102.

Myers, S. C., and Majluf, N. S. (1984). Corporate financing and investment decisions when firms have information that investors do not have. [doi: DOI: 10.1016/0304-405X(84)90023-0]. Journal of Financial Economics, 13(2), 187-221.

Opler, T. C., and Titman, S. (1994). Financial Distress and Corporate Performance. The Journal of Finance, 49(3), 1015-1040.

Qiu, M., and La, B. (2009). The Capital Structure Difference Across Australian Companies. SSRN eLibrary.

Rajan, R. G., and Zingales, L. (1995). What do we know about capital structure? Some evidence from international data. The Journal of Finance, 50(5), 1421-1460.

Ross, S. A. (1977). The Determination of Financial Structure: The Incentive-Signalling Approach. The Bell Journal of Economics, 8(1), 23-40.

Telser, L. G. (1980). A Theory of Self-Enforcing Agreements. The Journal of Business, 53(1), 27-44.

Titman, S. (1984). The effect of capital structure on a firm's liquidation decision. [doi: DOI: 10.1016/0304-405X(84)90035-7]. Journal of Financial Economics, 13(1), 137-151.

Titman, S., and Wessels, R. (1988). The Determinants of Capital Structure Choice. The Journal of Finance, 43(1), 1-19.

Twite, G. (2001). Capital Structure Choices and Taxes: Evidence from the Australian Dividend Imputation Tax System. [Article]. International Review of Finance, 2(4), 217.

Warner, J. B. (1977). Bankruptcy, absolute priority, and the pricing of risky debt claims. Journal of Financial Economics, 4(3), 239-276. 
Table 1 Variable Definitions

\begin{tabular}{|c|c|c|c|}
\hline Variable & Numerator & Denominator & Proxy \\
\hline Leverage & Total Book Value of Debt & $\begin{array}{l}\text { Book Value of Debt } \\
+ \text { Market Value of } \\
\text { Equity }\end{array}$ & Debt Level \\
\hline Warranty Provisions & Beginning of Fiscal Year Balance & Total Assets & $\begin{array}{l}\text { Firm's Level of } \\
\text { Warranty }\end{array}$ \\
\hline Size* & Book Value of Total Assets & & Firm Size \\
\hline $\begin{array}{l}\text { Asset Collateral } \\
\text { Value }\end{array}$ & Net Plant, Property and Equipment & Total Assets & Asset Tangibility \\
\hline$R O A$ & Net Income + Interest Expense* (1-Corporate Tax Rate) & Total Assets & Profitability \\
\hline ROA Volatility & $\begin{array}{l}\text { Standard Deviation of a Firm's ROA over 3, 4, } 5 \text { or } 6 \\
\text { Years. }\end{array}$ & & $\begin{array}{l}\text { Operating Income } \\
\text { Volatility }\end{array}$ \\
\hline Dividend Yield & Dividend per share & Price per share & Dividends Level \\
\hline Franked Dividend & $\begin{array}{l}\text { Dividend Dummy+\% Dividend Franking } \\
\text { (Dividend Dummy }=1 \text { if Dividend Yield }>0 \text { and zero } \\
\text { otherwise). }\end{array}$ & & Franked Dividend \\
\hline $\begin{array}{l}\text { Non-Debt Tax } \\
\text { Shields }\end{array}$ & $\begin{array}{l}\text { Operating Income-Interest Expense-(Tax } \\
\text { Expense/Corporate Tax Rate) }\end{array}$ & Total Assets & $\begin{array}{l}\text { Non-Debt Tax } \\
\text { Shields }\end{array}$ \\
\hline Tobin's $Q$ & Book Value of Debt + Market Value of Common Equity & Total Assets & Growth \\
\hline Total Accruals & $\begin{array}{l}(\Delta \text { Current Assets }-\Delta \text { Current Liabilities }-\Delta \text { Cash }+ \\
\Delta \text { Long Term Debt In Current Liabilities - Depreciation) }\end{array}$ & Lagged Assets & $\begin{array}{l}\text { Earnings } \\
\text { Management }\end{array}$ \\
\hline $\begin{array}{l}\text { Herfindahl Index } \\
\text { (Sales Based) }\end{array}$ & $\begin{array}{l}\text { Sum of the Squared Market Share of each Firm in its 4- } \\
\text { Digit GICS Code Industry }\end{array}$ & & $\begin{array}{l}\text { Industry } \\
\text { Concentration }\end{array}$ \\
\hline$R \& D$ Intensity & $\begin{array}{l}\text { R\&D Dummy * Intangible Assets (excluding goodwill) } \\
\text { (R\&D Dummy is subjectively determined based on } \\
\text { industry classification). }\end{array}$ & Total Assets & $\begin{array}{l}\text { Product } \\
\text { Uniqueness }\end{array}$ \\
\hline
\end{tabular}

*Log value of assets is used in regression analyses. 


\section{Table 2 Descriptive Statistics of Warranty Provisions}

The sample consists of 937 firm-years. The warranty data are from the annual reports for the fiscal years ending between 2007 and 2010. Warranty Provisions is the beginning of fiscal year balance normalised by total assets.

\begin{tabular}{|c|c|c|c|c|c|c|c|c|c|c|c|c|c|c|}
\hline & \multirow{2}{*}{$\begin{array}{l}\text { GICS } \\
\text { Code }\end{array}$} & \multirow{2}{*}{$\begin{array}{c}\text { Industry } \\
\text { Type }\end{array}$} & \multirow{2}{*}{$\begin{array}{c}\# \\
\text { Firm } \\
\text { Years }\end{array}$} & \multirow{2}{*}{$\begin{array}{l}\text { \% Firm } \\
\text { Years }\end{array}$} & \multirow{2}{*}{$\begin{array}{c}\# \\
\text { Explicit } \\
\text { Warranty } \\
\text { Firm } \\
\text { Years } \\
\end{array}$} & \multirow{2}{*}{$\begin{array}{c}\% \\
\text { Explicit } \\
\text { Warranty } \\
\text { Firm } \\
\text { Years } \\
\end{array}$} & \multirow{2}{*}{$\begin{array}{c}\# \\
\text { Implicit } \\
\text { Warranty } \\
\text { Firm } \\
\text { Years } \\
\end{array}$} & \multirow{2}{*}{$\begin{array}{c}\% \\
\text { Implicit } \\
\text { Warranty } \\
\text { Firm } \\
\text { Years } \\
\end{array}$} & \multirow{2}{*}{$\begin{array}{c}\text { \# No } \\
\text { Warranty } \\
\text { Firm } \\
\text { Years }\end{array}$} & \multirow{2}{*}{$\begin{array}{c}\% \text { No } \\
\text { Warranty } \\
\text { Firm } \\
\text { Years }\end{array}$} & \multicolumn{4}{|c|}{ Warranty Provisions } \\
\hline & & & & & & & & & & & Min & $\operatorname{Max}$ & Mean & Median \\
\hline Whole Sample & & & 937 & $100 \%$ & 151 & $16 \%$ & 350 & $37 \%$ & 436 & $47 \%$ & $0 \%$ & $2.287 \%$ & $0.115 \%$ & $0 \%$ \\
\hline Firms with WP $>0$ & & & & & & & & & & & $0.010 \%$ & $2.287 \%$ & $0.713 \%$ & $0.513 \%$ \\
\hline \multicolumn{15}{|l|}{ Industry Group Description } \\
\hline Energy & 1010 & NWI & 50 & $5.34 \%$ & - & - & - & - & 50 & $5.34 \%$ & - & - & - & - \\
\hline Materials & 1510 & NWI & 60 & $6.40 \%$ & - & - & - & - & 60 & $6.40 \%$ & - & - & - & - \\
\hline Capital Goods & 2010 & WI & 200 & $21.34 \%$ & 82 & $8.75 \%$ & 118 & $12.59 \%$ & - & - & $0.019 \%$ & $2.287 \%$ & $0.714 \%$ & $0.575 \%$ \\
\hline Commercial \& Professional Services & 2020 & WI & 81 & $8.64 \%$ & 13 & $1.39 \%$ & 68 & $7.26 \%$ & - & - & $0.010 \%$ & $2.287 \%$ & $0.500 \%$ & $0.089 \%$ \\
\hline Transportation & 2030 & NWI & 79 & $8.43 \%$ & - & - & - & - & 79 & $8.43 \%$ & - & - & - & - \\
\hline Automobile \& Components & 2510 & WI & 33 & $3.52 \%$ & 8 & $0.85 \%$ & 25 & $2.67 \%$ & - & - & $0.212 \%$ & $1.337 \%$ & $0.644 \%$ & $0.560 \%$ \\
\hline Consumer Durables \& Apparel & 2520 & WI & 37 & $3.95 \%$ & 16 & $1.71 \%$ & 21 & $2.24 \%$ & - & - & $0.118 \%$ & $2.287 \%$ & $1.021 \%$ & $0.925 \%$ \\
\hline Consumer Services & 2530 & WI & 26 & $2.77 \%$ & 4 & $0.43 \%$ & 22 & $2.35 \%$ & - & - & $0.215 \%$ & $0.378 \%$ & $0.309 \%$ & $0.322 \%$ \\
\hline Media & 2540 & NWI & 64 & $6.83 \%$ & - & - & - & - & 64 & $6.83 \%$ & - & - & - & - \\
\hline Retailing & 2550 & NWI & 107 & $11.42 \%$ & - & - & - & - & 107 & $11.42 \%$ & - & - & - & - \\
\hline Food \& Staples Retailing & 3010 & NWI & 12 & $1.28 \%$ & - & - & - & - & 12 & $1.28 \%$ & - & - & - & - \\
\hline Health Care Equipment \& Services & 3510 & WI & 40 & $4.27 \%$ & 10 & $1.07 \%$ & 30 & $3.20 \%$ & - & - & $0.090 \%$ & $1.766 \%$ & $0.808 \%$ & $0.458 \%$ \\
\hline Software \& Services & 4510 & WI & 49 & $5.23 \%$ & 7 & $0.75 \%$ & 42 & $4.48 \%$ & - & - & $0.192 \%$ & $2.287 \%$ & $0.816 \%$ & $0.287 \%$ \\
\hline $\begin{array}{l}\text { Technology Hardware \& Equipment } \\
\text { Semiconductors \& Semiconductor }\end{array}$ & 4520 & WI & 8 & $0.85 \%$ & 4 & $0.43 \%$ & 4 & $0.43 \%$ & - & - & $0.950 \%$ & $1.705 \%$ & $1.226 \%$ & $1.124 \%$ \\
\hline Equipment & 4530 & NWI & 10 & $1.07 \%$ & - & - & - & - & 10 & $1.07 \%$ & - & - & - & - \\
\hline Telecommunication Services & 5010 & NWI & 54 & $5.76 \%$ & - & - & - & - & 54 & $5.76 \%$ & - & - & - & - \\
\hline
\end{tabular}


Table 3 Descriptive Statistics of Variables and Correlations

The sample consists of 937 firm-years for the fiscal years 2007-2010. Leverage is the book value of total debt divided by the sum of the book value of debt and market value of common equity. Size is the firm's total assets (in \$m). Asset Collateral Value is net plant, property, and equipment divided by total assets. Non-Debt Tax Shields is operating income minus interest expense minus the ratio of tax expense to corporate tax rate all divided by total assets. Tobin's $Q$ is book value of debt plus the market value of common equity divided by total assets. $R O A$ is operating income divided by total assets. ROA Volatility is the standard deviation of ROA for the last 3-6 years. R\&D Intensity is R\&D dummy multiplied by intangible assets excluding goodwill divided by total assets. Herfindahl Index is the sum of the squared market share of each firm in its 4-digit GICS code industry. Total Accruals is the change in current assets minus the change in current liabilities minus the change in cash plus the change in long term debt in current liabilities minus depreciation divided by the lagged assets. Dividend Yield is the dividend per share divided by the price per share. Warranty Provisions (WP) is the beginning of fiscal year balance normalised by total assets. The bold values in the Pearson correlation panel denote significance at $10 \%$ level. All continuous variables are winsoriszed at the $1^{\text {st }}$ and $99^{\text {th }}$ percentiles.

\begin{tabular}{|c|c|c|c|c|c|c|c|c|c|c|c|}
\hline & Leverage & Size & $\begin{array}{c}\text { Asset } \\
\text { Collateral } \\
\text { Value }\end{array}$ & $\begin{array}{c}\text { Non-Debt } \\
\text { Tax } \\
\text { Shields }\end{array}$ & Tobin's $Q$ & $R O A$ & $\begin{array}{c}\text { ROA } \\
\text { Volatility }\end{array}$ & $\begin{array}{c}R \& D \\
\text { Intensity }\end{array}$ & $\begin{array}{l}\text { Herfindahl } \\
\text { Index }\end{array}$ & $\begin{array}{c}\text { Total } \\
\text { Accruals }\end{array}$ & $\begin{array}{l}\text { Dividend } \\
\text { Yield }\end{array}$ \\
\hline Min & 0.0000 & 1.485 & 0.0000 & -1.3776 & 0.2590 & -1.4608 & 0.0033 & 0.0000 & 0.0772 & -0.7418 & 0.0000 \\
\hline Max & 0.8143 & $36,175.000$ & 0.8211 & 0.2688 & 14.0468 & 0.3783 & 3.1561 & 0.6877 & 0.9076 & 0.7863 & 0.1690 \\
\hline Mean & 0.2030 & $1,759.288$ & 0.2445 & -0.0457 & 1.8622 & 0.0318 & 0.1310 & 0.0344 & 0.1986 & -0.0304 & 0.0385 \\
\hline Median & 0.1633 & 222.341 & 0.1758 & -0.0022 & 1.2180 & 0.0769 & 0.0332 & 0.0000 & 0.1428 & -0.0263 & 0.0368 \\
\hline \multicolumn{12}{|c|}{ Pearson Correlation Coefficients } \\
\hline Leverage & 1 & & & & & & & & & & \\
\hline Size & 0.3383 & 1 & & & & & & & & & \\
\hline Asset Collateral Value & 0.1805 & 0.2821 & 1 & & & & & & & & \\
\hline Non-Debt Tax Shields & 0.1786 & 0.4147 & 0.0971 & 1 & & & & & & & \\
\hline Tobin's $Q$ & -0.3282 & -0.2231 & -0.1171 & -0.2568 & 1 & & & & & & \\
\hline$R O A$ & 0.0928 & 0.3977 & 0.0860 & 0.9345 & -0.1231 & 1 & & & & & \\
\hline ROA Volatility & -0.1720 & -0.3758 & -0.1792 & -0.3999 & 0.2548 & -0.4159 & 1 & & & & \\
\hline$R \& D$ Intensity & 0.1044 & 0.0658 & -0.1498 & 0.0146 & -0.0015 & -0.0315 & 0.2046 & 1 & & & \\
\hline Herfindahl Index & -0.0462 & -0.0192 & -0.0196 & -0.1503 & 0.1663 & -0.1656 & 0.0824 & 0.0247 & 1 & & \\
\hline Total Accruals & 0.0379 & 0.0394 & -0.1355 & 0.0869 & -0.0052 & 0.0731 & 0.0191 & 0.0971 & -0.0534 & 1 & \\
\hline Dividend Yield & 0.2807 & 0.2089 & 0.0097 & 0.2544 & -0.2504 & 0.3198 & -0.2426 & -0.0151 & -0.0484 & 0.0409 & 1 \\
\hline Warranty Provisions* & -0.0902 & -0.1246 & -0.2298 & -0.0652 & -0.0051 & -0.0819 & 0.0855 & 0.1316 & 0.0053 & 0.0541 & 0.0638 \\
\hline
\end{tabular}

*The correlation coefficients between Warranty Provisions and the variables in the last line are for EWFs only. 


\title{
Table 4 Univariate Comparisons of Leverage and its Determinants by Firm Warranty Policy
}

\begin{abstract}
The sample consists of 937 firm-years for the fiscal years 2007-2010. Leverage is the book value of total debt divided by the sum of the book value of debt and market value of common equity. Size is the firm's total assets (in $\$ \mathrm{~m})$. Asset Collateral Value is net plant, property, and equipment divided by total assets. ROA is operating income divided by total assets. ROA Volatility is the standard deviation of ROA for the last 3-6 years. Dividend Yield is the dividend per share divided by the price per share. Non-Debt Tax Shields is operating income minus interest expense minus the ratio of tax expense to corporate tax rate all divided by total assets. Tobin's $Q$ is book value of debt plus the market value of common equity divided by total assets. Herfindahl Index is the sum of the squared market share of each firm in its 4-digit GICS code industry. Total Accruals is the change in current assets minus the change in current liabilities minus the change in cash plus the change in long term debt in current liabilities minus depreciation divided by the lagged assets. $R \& D$ Intensity is $R \& D$ dummy multiplied by intangible assets excluding goodwill divided by total assets. The first (last) two rows in each panel represent the mean (median) values of the two sub-samples. The bold values denote that the mean (median) is greater than that of the other subsample in the panel using a t-test (Kruskal-Wallis test) at $10 \%$ significance level. All continuous variables are winsorised at the $1^{\text {st }}$ and $99^{\text {th }}$ percentiles.
\end{abstract}

\begin{tabular}{|c|c|c|c|c|c|c|c|c|c|c|}
\hline Leverage & Size & $\begin{array}{c}\text { Asset } \\
\text { Collateral } \\
\text { Value }\end{array}$ & $R O A$ & $\begin{array}{c}\text { ROA } \\
\text { Volatility }\end{array}$ & $\begin{array}{l}\text { Dividend } \\
\text { Yield }\end{array}$ & $\begin{array}{c}\text { Non- } \\
\text { Debt Tax } \\
\text { Shields }\end{array}$ & $\begin{array}{c}\text { Tobin's } \\
Q\end{array}$ & $\begin{array}{l}\text { Herfindahl } \\
\text { Index }\end{array}$ & $\begin{array}{c}\text { Total } \\
\text { Accruals }\end{array}$ & $\begin{array}{c}R \& D \\
\text { Intensity }\end{array}$ \\
\hline \multicolumn{11}{|c|}{ Panel A: $1^{\text {st }}$ Row: 151 Warranty Firm-Yrs (EWF), $2^{\text {nd }}$ Row: 786 Non-Warranty Firm-Yrs (IWF+NWF) } \\
\hline 0.2227 & 918.353 & 0.2033 & 0.0633 & 0.0628 & 0.0427 & -0.0183 & 1.7321 & 0.1389 & -0.0148 & 0.0372 \\
\hline 0.1992 & $1,920.842$ & 0.2524 & 0.0257 & 0.1441 & 0.0377 & -0.0509 & 1.8871 & 0.2101 & -0.0334 & 0.0338 \\
\hline 0.2030 & 324.225 & 0.1739 & 0.0851 & 0.0230 & 0.0395 & 0.0049 & 1.3239 & 0.1268 & -0.0163 & 0.0051 \\
\hline 0.1548 & 214.285 & 0.1763 & 0.0749 & 0.0351 & 0.0357 & -0.0030 & 1.1995 & 0.1453 & -0.0299 & 0.0000 \\
\hline \multicolumn{11}{|c|}{ Panel B. $1^{\text {st }}$ Row: 501 Firm-Yrs of Firms in WI (EWF+IWF), $2^{\text {nd }}$ Row: 436 Firm-Yrs of firms in NWI } \\
\hline 0.2235 & 881.6759 & 0.2100 & 0.0517 & 0.1248 & 0.0421 & -0.0276 & 1.7536 & 0.1442 & -0.0157 & 0.0382 \\
\hline 0.1794 & $2,767.7378$ & 0.2842 & 0.0088 & 0.1382 & 0.0344 & -0.0664 & 1.9869 & 0.2612 & -0.0473 & 0.0300 \\
\hline 0.1919 & 228.7940 & 0.1555 & 0.0813 & 0.0290 & 0.0395 & 0.0001 & 1.2276 & 0.1272 & -0.0214 & 0.0000 \\
\hline 0.1261 & 218.0425 & 0.2125 & 0.0682 & 0.0353 & 0.0296 & -0.0056 & 1.1964 & 0.2205 & -0.0340 & 0.0000 \\
\hline \multicolumn{11}{|c|}{ Panel C. $1^{\text {st }}$ Row: 350 Firm-Yrs without Warranty Provisions in WI(IWF), $2^{\text {nd }}$ Row: 436 Firm-Yrs in NWI } \\
\hline 0.2239 & 865.8525 & 0.2129 & 0.0467 & 0.1515 & 0.0418 & -0.0317 & 1.7628 & 0.1465 & -0.0161 & 0.0386 \\
\hline 0.1794 & $2,767.7378$ & 0.2842 & 0.0088 & 0.1382 & 0.0344 & -0.0664 & 1.9869 & 0.2612 & -0.0473 & 0.0300 \\
\hline 0.1853 & 210.8415 & 0.1484 & 0.0791 & 0.0340 & 0.0396 & -0.0010 & 1.2043 & 0.1272 & -0.0240 & 0.0000 \\
\hline 0.1261 & 218.0425 & 0.2125 & 0.0682 & 0.0353 & 0.0296 & -0.0056 & 1.1964 & 0.2205 & -0.0340 & 0.0000 \\
\hline \multicolumn{11}{|c|}{ Panel D. ${ }^{\text {st }}$ Row: 151 Firm-Yrs with Warranty Provisions(EWF), $2^{\text {nd }}$ Row: 350 Firm-Yrs w/o Warranty Provisions in WI } \\
\hline 0.2227 & 918.3527 & 0.2033 & 0.0633 & 0.0628 & 0.0427 & -0.0183 & 1.7321 & 0.1389 & -0.0148 & 0.0372 \\
\hline 0.2239 & 865.8525 & 0.2129 & 0.0467 & 0.1515 & 0.0418 & -0.0317 & 1.7628 & 0.1465 & -0.0161 & 0.0386 \\
\hline 0.2030 & 324.2250 & 0.1739 & 0.0851 & 0.0230 & 0.0395 & 0.0049 & 1.3239 & 0.1268 & -0.0163 & 0.0051 \\
\hline 0.1853 & 210.8415 & 0.1484 & 0.0791 & 0.0340 & 0.0396 & -0.0010 & 1.2043 & 0.1272 & -0.0240 & 0.0000 \\
\hline
\end{tabular}




\section{Table 5 OLS Regressions of Leverage on Warranty Provisions and other Determinants}

The sample consists of 937 firm-years for the fiscal years 2007-2010. The dependent variable in all models is Leverage which is the book value of total debt divided by the sum of the book value of debt and market value of common equity. Warranty Provisions is the beginning of fiscal year balance normalised by total assets. Size is the $\log$ of firm's total assets. ROA is operating income divided by total assets. ROA Volatility is the standard deviation of ROA for the last 3-6 years. Dividend Yield is the dividend per share divided by the price per share. Franked Dividend is the sum of Dividend Dummy and percentage of dividend franking where Dividend Dummy equals 1 if dividend yield is greater than zero, and zero otherwise. Asset Collateral Value is net plant, property, and equipment divided by total assets. Tobin's $Q$ is book value of debt plus the market value of common equity divided by total assets. Herfindahl Index is the sum of the squared market share of each firm in its 4-digit GICS code industry. Total Accruals is the change in current assets minus the change in current liabilities minus the change in cash plus the change in long term debt in current liabilities minus depreciation divided by the lagged assets. Non-Debt Tax Shields is operating income minus interest expense minus the ratio of tax expense to corporate tax rate all divided by total assets. $R \& D$ Intensity is $R \& D$ Dummy multiplied by intangible assets excluding goodwill divided by total assets. All continuous variables are winsorised at the $1^{\text {st }}$ and $99^{\text {th }}$ percentiles. P-values are presented in parentheses. *, **, and *** denote significance at $1 \%, 5 \%$, and $10 \%$ level respectively.

\begin{tabular}{|c|c|c|}
\hline \multirow[b]{2}{*}{ Intercept } & \multicolumn{2}{|c|}{ Whole Sample } \\
\hline & $\begin{array}{c}-0.405^{*} \\
(0.000)\end{array}$ & $\begin{array}{c}-0.414^{*} \\
(0.000)\end{array}$ \\
\hline Warranty Provisions & $\begin{array}{l}-2.407 \\
(0.122)\end{array}$ & $\begin{array}{c}-2.801^{* * *} \\
(0.069)\end{array}$ \\
\hline Size & $\begin{array}{l}0.030 * \\
(0.000)\end{array}$ & $\begin{array}{l}0.031 * \\
(0.000)\end{array}$ \\
\hline$R O A$ & $\begin{array}{c}-0.345^{*} \\
(0.000)\end{array}$ & $\begin{array}{c}-0.390 * \\
(0.000)\end{array}$ \\
\hline ROA Volatility & $\begin{array}{c}-0.023 \\
(0.175)\end{array}$ & $\begin{array}{l}-0.020 \\
(0.213)\end{array}$ \\
\hline Dividend Yield & & $\begin{array}{l}1.260 * \\
(0.000)\end{array}$ \\
\hline Franked Dividend & & $\begin{array}{c}-(0.028)^{*} \\
(0.004)\end{array}$ \\
\hline Asset Collateral Value & $\begin{array}{l}0.089 * \\
(0.003)\end{array}$ & $\begin{array}{l}0.088 * \\
(0.003)\end{array}$ \\
\hline Tobin's $Q$ & $\begin{array}{c}-0.013^{*} \\
(0.000)\end{array}$ & $\begin{array}{c}-0.009 * \\
(0.007)\end{array}$ \\
\hline Herfindahl Index & $\begin{array}{c}0.109 \\
(0.631)\end{array}$ & $\begin{array}{c}0.009 \\
(0.969)\end{array}$ \\
\hline Total Accruals & $\begin{array}{c}0.030 \\
(0.365)\end{array}$ & $\begin{array}{c}0.032 \\
(0.317)\end{array}$ \\
\hline Non-Debt Tax Shields & $\begin{array}{l}0.327 * \\
(0.000)\end{array}$ & $\begin{array}{l}0.363^{*} \\
(0.000)\end{array}$ \\
\hline$R \& D$ Intensity & $\begin{array}{c}0.141^{* *} \\
(0.027)\end{array}$ & $\begin{array}{c}0.119 * * * \\
(0.057)\end{array}$ \\
\hline Fixed Year Effects & Yes & Yes \\
\hline 4 Digit GICS code Industry Fixed Effects & Yes & Yes \\
\hline $\begin{array}{l}\mathrm{N} \\
\mathrm{R}-\text { Squared (Adj R-Square) }\end{array}$ & $\begin{array}{c}937 \\
34 \%(32 \%)\end{array}$ & $\begin{array}{c}906 \dagger \\
37 \%(35 \%)\end{array}$ \\
\hline
\end{tabular}

† The addition of Franked Dividend Variable resulted in a loss of 31 observations due to missing values. 


\section{Table 6 OLS Regressions of Leverage on Warranty Provisions for Warranty Industries}

The sample consists of 484 firm-years of firms in warranty industries for the fiscal years 2007-2010. The dependent variable in all models is Leverage which is the book value of total debt divided by the sum of the book value of debt and market value of common equity. Warranty Provisions is the beginning of fiscal year balance normalised by total assets. Size is the log of firm's total assets. ROA is operating income divided by total assets. ROA Volatility is the standard deviation of ROA for the last 3-6 years. Dividend Yield is the dividend per share divided by the price per share. Franked Dividend is the sum of Dividend Dummy and percentage of dividend franking where Dividend Dummy equals 1 if dividend yield is greater than zero, and zero otherwise. Asset Collateral Value is net plant, property, and equipment divided by total assets. Tobin's $Q$ is book value of debt plus the market value of common equity divided by total assets. Herfindahl Index is the sum of the squared market share of each firm in its 4-digit GICS code industry. Total Accruals is the change in current assets minus the change in current liabilities minus the change in cash plus the change in long term debt in current liabilities minus depreciation divided by the lagged assets. Non-Debt Tax Shields is operating income minus interest expense minus the ratio of tax expense to corporate tax rate all divided by total assets. $R \& D$ Intensity is $R \& D$ Dummy multiplied by intangible assets excluding goodwill divided by total assets. All continuous variables are winsorised at the $1^{\text {st }}$ and $99^{\text {th }}$ percentiles. P-values are presented in parentheses. *, **, and $* * *$ denote significance at $1 \%, 5 \%$, and $10 \%$ level respectively.

\begin{tabular}{|c|c|c|c|}
\hline & \multicolumn{3}{|c|}{ Warranty Industries } \\
\hline & $\begin{array}{l}\text { Warranty } \\
\text { Industries }\end{array}$ & $\begin{array}{l}\text { Durable Goods } \\
\text { Industries }\end{array}$ & $\begin{array}{c}\text { Non-Durable } \\
\text { Goods Industries }\end{array}$ \\
\hline Intercept & $\begin{array}{c}-0.428 * * \\
(0.021)\end{array}$ & $\begin{array}{c}-0.345 \\
(0.178)\end{array}$ & $\begin{array}{c}-0.377 \\
(0.248)\end{array}$ \\
\hline Warranty Provisions & $\begin{array}{l}-2.362 \\
(0.139)\end{array}$ & $\begin{array}{l}-1.425 \\
(0.458)\end{array}$ & $\begin{array}{c}-6.629 * * \\
(0.057)\end{array}$ \\
\hline Size & $\begin{array}{c}0.031^{*} \\
(0.000)\end{array}$ & $\begin{array}{l}0.028^{*} \\
(0.000)\end{array}$ & $\begin{array}{l}0.042^{*} \\
(0.000)\end{array}$ \\
\hline$R O A$ & $\begin{array}{c}-0.372 * \\
(0.002)\end{array}$ & $\begin{array}{c}-0.414^{* *} \\
(0.010)\end{array}$ & $\begin{array}{c}-0.452^{* *} \\
(0.017)\end{array}$ \\
\hline ROA Volatility & $\begin{array}{c}-0.019 \\
(0.436)\end{array}$ & $\begin{array}{l}-0.045 \\
(0.172)\end{array}$ & $\begin{array}{c}0.082 * * \\
(0.077)\end{array}$ \\
\hline Dividend Yield & $\begin{array}{l}0.950 * \\
(0.007)\end{array}$ & $\begin{array}{c}0.831 * * \\
(0.071)\end{array}$ & $\begin{array}{c}0.849 \\
(0.129)\end{array}$ \\
\hline Franked Dividend & $\begin{array}{c}-(0.013) \\
(0.404)\end{array}$ & $\begin{array}{c}-(0.008) \\
(0.719)\end{array}$ & $\begin{array}{c}-(0.016) \\
(0.491)\end{array}$ \\
\hline Asset Collateral Value & $\begin{array}{l}0.125 * \\
(0.005)\end{array}$ & $\begin{array}{l}0.200 * \\
(0.002)\end{array}$ & $\begin{array}{c}0.010 \\
(0.871)\end{array}$ \\
\hline Tobin's $Q$ & $\begin{array}{c}-0.016 * \\
(0.006)\end{array}$ & $\begin{array}{c}-0.026 * \\
(0.007)\end{array}$ & $\begin{array}{l}-0.007 \\
(0.327)\end{array}$ \\
\hline Herfindahl Index & $\begin{array}{c}0.485 \\
(0.542)\end{array}$ & $\begin{array}{c}0.368 \\
(0.741)\end{array}$ & $\begin{array}{c}-1.897 \\
(0.402)\end{array}$ \\
\hline Total Accruals & $\begin{array}{c}0.034 \\
(0.447)\end{array}$ & $\begin{array}{c}0.061 \\
(0.278)\end{array}$ & $\begin{array}{c}0.112 \\
(0.212)\end{array}$ \\
\hline Non-Debt Tax Shields & $\begin{array}{c}0.326 * * \\
(0.012)\end{array}$ & $\begin{array}{c}0.321^{* * * *} \\
(0.057)\end{array}$ & $\begin{array}{l}0.622 * \\
(0.005)\end{array}$ \\
\hline$R \& D$ Intensity & $\begin{array}{c}-0.024 \\
(0.796)\end{array}$ & $\begin{array}{c}0.016 \\
(0.885)\end{array}$ & $\begin{array}{l}-0.102 \\
(0.580)\end{array}$ \\
\hline Fixed Year Effects & $\begin{array}{l}\text { Yes } \\
\text { Yes }\end{array}$ & $\begin{array}{l}Y e s \\
Y \rho s\end{array}$ & Yes \\
\hline $\mathrm{N}$ & 484 & 307 & 177 \\
\hline R-Squared & $31 \%$ & $27 \%$ & $46 \%$ \\
\hline
\end{tabular}

